\title{
Premarital Sexual Behaviour and its Impact on Health among Adolescents
}

\author{
Ram Bahadur Shrestha*
}

\begin{abstract}
More than two-thirds of young people in developed nations have sexual intercourse while still in their teens. The most vulnerable group of premarital sexual behaviour are youths and adolescents. The aim of the study is to assess factors affecting premarital sex behaviours among adolescents and its impact on health. This study is based on the review of secondary information published by the relevant organization and authors in Nepal and beyond. Study materials were primarily identified searching through Electronic databases and Software bases. Age group of $10-19$ called as adolescents during the period, there is drastic development in physical, cognitive, social and emotional development. There are multidimensional factors that leads to premarital sexual behaviour. Parent relationship with their children and family environment, societal environment, cultural and traditional rules and values, economic condition, school environment, peer's relationship, love and affairs, communications (mobiles, internet-pone movies etc.) and rules and regulation are the risk factors that affect in premarital sexual behaviour of the adolescents. Sex after marriage is fruitful but having a premarital sex with mutual understanding with full protection is not a big issue. Unwanted pregnancy, teenage pregnancy, abortion, STIs, HIVIAIDS, regrets, guilt, loss of self-respect, depression, loss of family support, substance abuse and even suicidal death are the health impact of premarital sexual behaviour among adolescents.
\end{abstract}

Keywords: Adolescents, premarital sex, social network, risk factor, teenage pregnancy.

\section{Introduction}

Sex is a most beautiful gift of the nature to humans. However, regarding premarital sex, every teen and engaged couples perhaps have common question of "Is it ok to have premarital sex?" The belief of premarital sex was different from each other some think that it is ok and is a natural process to have and some others think that it is however, a crime (Cavendish, 20l0).

Premarital sexual behaviour or sex before marriage is the sexual activity practiced by people before they are married. The Bible considers premarital sex as fornication. Fornication is sexual intercourse between people who are not married to each other. Fornication comes from Latin fornicari that means vaulted, which become the nick name for brothel, because prostitutes operated in a vaulted underground cavern in Rome. Alternative terms for premarital are nonmarital sex, youthful sex, adolescent sex and young-adult sex (Cavendish, 20I0).

Premarital sex, since about the 1960s, has become more widely acceptable, especially in Western countries. According to UNICEF (200I), 10 out of 12 in developed nations more

\footnotetext{
* Master in Public Health, Program Coordinator, Purbanchal University College of Medical and Allied Sciences (PUCMAS), National Institute for Development and Research (NIDR)

Email: ramshrestha30@gmail.com
} 
than two-thirds of young people have had sexual intercourse while still in their teens. In Denmark, Finland, Germany, Iceland, Norway, the United Kingdom and the United States, the proportion is over $80 \%$. In Australia, the United Kingdom and the United States, approximately $25 \%$ of 15 year olds and $50 \%$ of 17 year olds have sex. Data from the 2002 survey indicate that by age $20,77 \%$ of Americans had sex by age 20 , and of that percent, $75 \%$ had premarital sex (Finer, 2007).

Premarital sexual behaviour is not accepted by culturally and socially. The more vulnerable group is unmarried youths and adolescents. Sixteen percent of women age 25-49 had first sexual intercourse by age 15, 54 percent by age 18, and 72 percent by age 20 . The median age at first intercourse among women age 25-49 (17.7 years) is only marginally higher than the median age at marriage (17.5 years), suggesting that Nepalese women in general initiate sexual intercourse at the time of their first marriage, with few exceptions (NDHS, 20II). According to Nepal Adolescent and Youth Survey 2010/1 I, 17\% of young unmarried people ever fall in love and this proportion is higher among boys. The mean age at first sexual intercourse for the young population is 17.5 years. About $6 \%$ of boys before the age of 15 years were engaged in sexual intercourse. According to study done by FHI 360 in $200 \mathrm{I}$, reported that $15 \%$ of adolescent boys engaged in premarital sexual intercourse (Population Division, Government of Nepal, Ministry of Health and Population, 2010). Another study among young by Puri and Cleland in 2006 found that unmarried 35\% boys and 16\% girls have experience of sex. Likewise, Adhikari and Tamang (2009) in their study found that almost $40 \%$ of young men had premarital sex.

Premarital sexual behaviour may lead several health problems i.e. sexually transmitted infections (STIs), human immune virus and acquired immune deficiency syndrome (HIVIAIDS), unwanted pregnancies (especially teenage pregnancy), unsafe abortions, emotional disturbances, baby dumping and maternal deaths (United Nations - Youth, 2003).

Several studies have shown factors related to premarital sex in three interfaces. First, at individual level, this includes demographic factors (age, sex and ethnicity), love, affair, loneliness etc. Secondly, at family level like family type, family income, occupation, broken families and bad parenting. Thirdly, at institutional level, that includes social network, organization, communication (mobile phones, internet, books and magazines, radio and television), policies and laws (World Health Organization, Regional Office South-East Asia)(DN Bhatta, 20I3). The overall aim of the study is to assess factors affecting premarital sex behaviours among adolescent and its impact on health.

\section{Methods}

This study was based on the review of secondary information published by the relevant organization and authors in Nepal and beyond. Studies were primarily identified searching through electronic data bases (HINARI, PubMed, Google search and Google scholar) and software bases (EndNote X7). Out of 1600 articles, only 15 were used in this study. For selection of English language, having full article that can be freely accessible was set as selection criteria. Furthermore, all types of a study done by researcher in premarital sex among adolescent and youth within a period between $200 \mathrm{I}$ to 2016 were also used as a study selection criteria. 


\section{Results}

\section{Factor Affecting Premarital Sexual Behaviour}

The important factors that lead premarital sexual behaviour like individual, family, institutional are dealt based on secondary data.

\section{Individual level}

Age, sex, peer relationship, peer pressure, love and affaire etc. are significant factors that lead to premarital sexual behaviour. From review of different studies, it is revealed that there are strong relationships between age group and premarital sex. Adolescent of late adolescent especially 18-19 are most common to have premarital sexual behaviour than early adolescents (Table I). Male are more violent than female and they can express their feeling easily than female especially in south-east countries. Review studies also shows that males are exposed to have premarital sexual behaviour than female (Table I).

During adolescence naturally, adolescents are more attracted towards opposite sex. Friendship, love and affaire are common during adolescence. Different studies show that good peer relationship can trust each other. They can share their problems, happiness, sexual desire, various quarries, feeling etc. Studies also shows, sexual behaviours within good peer were significantly less than the youths having poor peer norms $(\chi 2=22.377$ and $P<0.00 I)$ (BC, 2013) which is shown in Table 1.

Table I

Individual level factor for having premarital sexual behaviour

\begin{tabular}{|c|c|c|c|c|c|}
\hline $\begin{array}{l}\mathbf{S} \\
\mathbf{N}\end{array}$ & Study & Study Design & $\begin{array}{l}\text { Sample } \\
\text { Size } \\
\end{array}$ & Finding & Remark \\
\hline \multicolumn{6}{|c|}{ Age } \\
\hline I & $\begin{array}{l}\text { Bhatta DN et al., } \\
\text { (Bhatta, 20/3) }\end{array}$ & Cross-sectional study & 324 & $58.60 \%$ & $18-19$ age \\
\hline 2 & $\begin{array}{l}\text { Mulugeta and } \\
\text { Berhane et al }\end{array}$ & Cross-sectional survey & 3984 & $68.70 \%$ & $16-18$ age \\
\hline 3 & $\begin{array}{l}\text { BC GB, Basel PL et } \\
\text { al }(B C, 2013)\end{array}$ & $\begin{array}{l}\text { Cross-sectional } \\
\text { descriptive study }\end{array}$ & 235 & $13.50 \%$ & $18-19$ age \\
\hline \multicolumn{6}{|c|}{ a. } \\
\hline I & $\begin{array}{l}\text { Paudel D. et al., } \\
\text { (Paudel, 20|3) }\end{array}$ & $\begin{array}{l}\text { cross-sectional } \\
\text { descriptive study }\end{array}$ & 400 & $\begin{array}{l}\text { Male }=62.8 \text { and } \\
\text { Female }=20.9 \%\end{array}$ & \\
\hline 2 & $\begin{array}{l}\text { Bhatta DN et al., } \\
\text { (Bhatta, 20/3) }\end{array}$ & Cross-sectional study & 324 & $\begin{array}{c}\text { Male }=32.6 \% \text { and } \\
\text { Female }=13.7 \%\end{array}$ & \\
\hline 3 & $\begin{array}{l}\text { Chai Podhisita, } \\
\text { Peter Xenos, and } \\
\text { Anchalee Varangrat } \\
\text { et al (Podhisita, } \\
\text { 200I) }\end{array}$ & $\begin{array}{l}\text { Family and Youth Survey } \\
\text { (FAYS) }\end{array}$ & 2179 & $\begin{array}{c}\text { Male }=46.7 \% \text { and } \\
\text { Female }=9.0 \%\end{array}$ & \\
\hline 4 & $\begin{array}{l}\text { BC GB, Basel PL et } \\
\text { al., (BC, 2013) }\end{array}$ & $\begin{array}{l}\text { Cross-sectional } \\
\text { descriptive study }\end{array}$ & 235 & $\begin{array}{c}\text { Male }=44.8 \% \text { and } \\
\text { Female }=4.2 \%\end{array}$ & $\begin{array}{r}\chi^{2}= \\
56.74 \text { and } \\
P<0.01\end{array}$ \\
\hline
\end{tabular}




\begin{tabular}{|c|c|c|c|c|c|}
\hline \multicolumn{6}{|c|}{ Peer Relationship/Love and Affaire } \\
\hline I & $\begin{array}{l}\text { Bhatta DN et al., } \\
\text { (Bhatta, 20I3) }\end{array}$ & Cross-sectional study & 324 & $\begin{array}{l}\text { Among the boys } 57.1 \% \text { and } \\
\text { among the girls } 55.6 \% \text { had } \\
\text { the first sexual intercourse } \\
\text { with their girlfriends and } \\
\text { boy friends }\end{array}$ & \\
\hline 2 & $\begin{array}{l}\text { L. Gibney et al } \\
\text { (Gibney, 2003) }\end{array}$ & Cross-sectional study & 388 & Girlfriend $=21.9 \%$ (have sex) & \\
\hline 3 & $\begin{array}{l}\text { BC GB, Basel PL et } \\
\text { al., (BC, 2013) }\end{array}$ & $\begin{array}{l}\text { Cross-sectional } \\
\text { descriptive study }\end{array}$ & 235 & $\begin{array}{l}\text { Youths who had good peer } \\
\text { norms were significantly less } \\
\text { likely to experience } \\
\text { premarital sex behaviours } \\
\text { than youths who had poor } \\
\text { peer norm }\end{array}$ & $\begin{array}{r}\chi 2= \\
22.377 \\
\text { and } \\
P<0.001\end{array}$ \\
\hline 4 & $\begin{array}{l}\text { Nafissatou Diop- } \\
\text { Sidibe et al., }\end{array}$ & Secondary data analysis & 2681 & $\begin{array}{l}61 \% \text { of females and } 55 \% \text { of } \\
\text { males have Boyfriend or } \\
\text { girlfriend; reported having } \\
\text { such a partner at the time of } \\
\text { Overall, } 68 \% \text { of participants } \\
\text { had ever had sex }\end{array}$ & \\
\hline 5 & $\begin{array}{l}\text { Chi Chiao and } \\
\text { Chin-Chun Yi et al/. } \\
(Y \mathrm{Y}, 20 \mathrm{II})\end{array}$ & $\begin{array}{l}\text { Taiwan Youth Project } \\
\text { survey (data are used, } \\
\text { multistage random } \\
\text { sampling was drawn and } \\
\text { develop two cohorts of } \\
\text { students) }\end{array}$ & 3525 & $\begin{array}{l}\text { Youth who perceived their } \\
\text { best friends as being } \\
\text { sexually active had higher } \\
\text { odds of having premarital } \\
\text { sex }(O R=2.08)\end{array}$ & \\
\hline 6 & $\begin{array}{l}\text { Chi Chiao and } \\
\text { Chin-Chun Yi et al } \\
(Y i, 201 \mathrm{I})\end{array}$ & $\begin{array}{l}\text { Taiwan Youth Project } \\
\text { survey (data are used, } \\
\text { multistage random } \\
\text { sampling was drawn and } \\
\text { develop two cohorts of } \\
\text { students) }\end{array}$ & 3525 & $\begin{array}{l}\text { There are significant } \\
\text { association between } \\
\text { perceived peer influence, } \\
\text { romantic-related } \\
\text { characteristics, and context- } \\
\text { related factors with } \\
\text { adolescent premarital sex } \\
\text { engagement remained } \\
(\mathrm{OR=54.80)}\end{array}$ & \\
\hline
\end{tabular}

\section{Family Level}

Family is a group of biologically related persons living together and sharing the common, roof, kitchen and purse. Family environment directly have relationship between premarital sexual behavioural in adolescent period. Review studies show that there is relationship between parent and adolescents. Especially, mother have greater roles than other member in family. From this we can conclude that family environment has direct relationship to have premarital sexual behaviour in adolescents (Table 2). 
Table 2

Family level factor for having premarital sexual behaviour

\begin{tabular}{|c|c|c|c|c|c|}
\hline $\mathbf{S}$ & Study & Study Design & $\begin{array}{l}\text { Sample } \\
\text { Size }\end{array}$ & Finding & Remark \\
\hline \multicolumn{6}{|c|}{ Family Relationship } \\
\hline $\mathbf{I}$ & $\begin{array}{l}\text { Susant T. Robert and Barbara L. } \\
\text { Kennedy et al (Kennedy, 2006) }\end{array}$ & $\begin{array}{l}\text { Descriptive/ } \\
\text { correlation design }\end{array}$ & 100 & $\begin{array}{l}\text { Parents support were } \\
\text { inversely correlated to } \\
\text { sexual behaviour }\end{array}$ & $\begin{array}{l}\mathrm{r}=-0.218 \\
\text { and } \mathrm{P}=0.05\end{array}$ \\
\hline 2 & BC GB, Basel PL et al/. (BC, 20I3) & $\begin{array}{l}\text { Cross-sectional } \\
\text { descriptive study }\end{array}$ & 235 & $\begin{array}{l}\text { Without } \\
\text { relationship }=25.8 \% \text { and } \\
\text { with } \\
\text { relationship }=18.6 \%\end{array}$ & $\begin{array}{l}\text { Good } \\
\text { Relationshi } \\
\mathrm{P}(\chi 2= \\
4.57 \text { and } \\
\mathrm{P}=0.032)\end{array}$ \\
\hline 3 & Inazu \& Fox (1980) (Miller, 200I) & NA & NA & $\begin{array}{l}\text { Closeness of } \\
\text { mother/daughter } \\
\text { relationship strongly } \\
\text { associated with } \\
\text { daughter not having } \\
\text { intercourse }\end{array}$ & $\begin{array}{l}\text { Synthesis } \\
\text { from } \\
\text { review } \\
\text { article }\end{array}$ \\
\hline 4 & $\begin{array}{l}\text { Weinstein \& Thorton (1989) (Miller, } \\
\text { 200I) }\end{array}$ & NA & NA & $\begin{array}{l}\text { Close mother/child } \\
\text { relationships increase } \\
\text { effect of mothers } \\
\text { attitudes on teen } \\
\text { sexual behaviours; if } \\
\text { mother has no } \\
\text { permissive attitudes, } \\
\text { teens least likely to } \\
\text { have sex when they } \\
\text { have a close } \\
\text { mother/child relation }\end{array}$ & $\begin{array}{l}\text { Synthesis } \\
\text { from } \\
\text { review } \\
\text { article }\end{array}$ \\
\hline 5 & Whitbeck et al., (I992) (Miller, 200I) & NA & NA & $\begin{array}{l}\text { Parental support } \\
\text { related to teen not } \\
\text { having intercourse } \\
\text { experience }\end{array}$ & $\begin{array}{l}\text { Synthesis } \\
\text { from } \\
\text { review } \\
\text { article }\end{array}$ \\
\hline 6 & Feldman \& Brown (1993) (Miller, 200I) & NA & NA & $\begin{array}{l}\text { Quality of parent/child } \\
\text { relations and positive } \\
\text { child rearing practices } \\
\text { inversely related to } \\
\text { sons' number of sex } \\
\text { partners } 4 \text { years later }\end{array}$ & $\begin{array}{l}\text { Synthesis } \\
\text { from } \\
\text { review } \\
\text { article }\end{array}$ \\
\hline
\end{tabular}

\section{Institutional Factors}

Adolescent sexual health is multi-dimensional. Their health is related to institutional level also. Like rules and regulation, policies, community leader, community organization, education institutional environment and communication facilities including internet have direct and indirect relationship with adolescent sexual behaviour especially premarital sex.

Referring to finding of review studies, we can conclude that there is a direct relationship within institutional level factor for having premarital sexual behaviour (Table 3). 
Table 3

Institutional factor for having premarital sexual behaviour

\begin{tabular}{|c|c|c|c|c|c|}
\hline $\mathbf{S N}$ & Study & Study Design & Sample & Finding & Remark \\
\hline & & $\mathrm{Co}$ & mmunic & tion & \\
\hline I & $\begin{array}{l}\text { Mulugeta and } \\
\text { Berhane et al } \\
\text { (Berhane, 2014) }\end{array}$ & Cross-sectional survey & 3984 & $\begin{array}{l}\text { Watching pornographic video } \\
{[A O R=10.15,95 \% \mathrm{Cl}:(6.63,15.53)]}\end{array}$ & \\
\hline 2 & $\begin{array}{l}\text { Chi Chiao and Chin- } \\
\text { Chun Yi et al (Yi, } \\
\text { 20II) }\end{array}$ & $\begin{array}{l}\text { Taiwan Youth Project } \\
\text { survey (data are used, } \\
\text { multistage random } \\
\text { sampling was drawn and } \\
\text { develop two cohorts of } \\
\text { students) }\end{array}$ & 3525 & $\begin{array}{l}\text { Youth who had been exposed to } \\
\text { pornography were also more likely to } \\
\text { engage in adolescent premarital sex } \\
(\mathrm{OR}=2.03)\end{array}$ & \\
\hline & ohol Drinking, Smo & ing and drug abuse & & & \\
\hline I & $\begin{array}{l}\text { BC GB, Basel PL et } \\
\text { al., (BC, 2013) }\end{array}$ & $\begin{array}{l}\text { Cross-sectional } \\
\text { descriptive study }\end{array}$ & 235 & Alcohol drink $=34.6 \%$ & $\begin{array}{r}\chi 2= \\
27.324 \\
\text { and } \\
P<0.001\end{array}$ \\
\hline 2 & $\begin{array}{l}\text { Chiao et al., (Chiao, } \\
2012 \text { ) }\end{array}$ & Cohort study & $5,54 I$ & $\begin{array}{l}\text { Adolescent cigarette use was still } \\
\text { significantly associated with higher odds of } \\
\text { premarital sex for males only (AOR = } 2.0 \text {; } \\
95 \% \mathrm{Cl}=1.4-4.0 \text { ) }\end{array}$ & \\
\hline & $\begin{array}{l}\text { Chiao et al (Chiao, } \\
2012 \text { ) }\end{array}$ & Cohort study & 5,541 & $\begin{array}{l}\text { Adolescent alcohol was significantly related } \\
\text { to engaging in premarital sex for females } \\
\text { only }(A O R=2.0 ; 95 \% \mathrm{Cl}=1.4-4.0) \text {. }\end{array}$ & \\
\hline & $\begin{array}{l}\text { Chiao et al., (Chiao, } \\
\text { 2012) }\end{array}$ & Cohort study & 5,541 & $\begin{array}{l}\text { Male college students with heavier } \\
\text { adolescent drinking were } 2.7 \text { times more } \\
\text { likely to have premarital sex than } \\
\text { abstainers; this result continued to be } \\
\text { found among females categorized as light } \\
\text { drinkers (AOR }=2.1 ; 95 \% \mathrm{Cl}=1.2-3.6 \text { ). }\end{array}$ & \\
\hline 3 & $\begin{array}{l}\text { Bhatta DN et al., } \\
\text { (Bhatta, 20I3) }\end{array}$ & Cross-sectional study & 324 & $\begin{array}{l}\text { There was highly significant relationship } \\
(P<0.0 I) \text { between smoking, alcohol } \\
\text { drinking, and drug using habit of their } \\
\text { peers with the sex }\end{array}$ & \\
\hline
\end{tabular}

\section{Health Impact of Premarital Sexual Behaviour among Adolescents}

Health is a positive, optimal and dynamic state of condition of physical, mental, social and spiritual wellbeing and harmonious development in the absence of disease or infirmity which leads to the enjoyment of socio-economically productive and complete life adjusted to environments (Pradhanaga, 2018). Health of adolescent is very crucial. Any small mistake or any unusual habit practice by adolescents leads to bad health throughout whole life. Adolescence is a life phase in which the opportunities for health are great and future patterns of adult health are established. Health in adolescence is the result of interactions between prenatal and early childhood development and the specific biological and social-role changes that accompany puberty, shaped by social determinants and risk and protective factors that affect the uptake of health-related behaviours (Sawyer, 2012).

Study reflects that different culture and religion do not give permission to have premarital sex. Along with this our society, growth and development of mind towards premarital sex was not 
acceptable. Study also reflects that most of people agree that pre-marital sex is a bad habit. Moreover, premarital sexual behaviour among adolescent have direct and indirect impact on health like unwanted pregnancy, teen age pregnancy, abortion, STI, HIVIAIDS, regrets, guilt loss of self-respect, depression, loss of family support, substance abuse, depression, loss of selfesteem and suicidal death (Table 4).

\section{Table 4}

Health impact due to premarital sexual behaviour

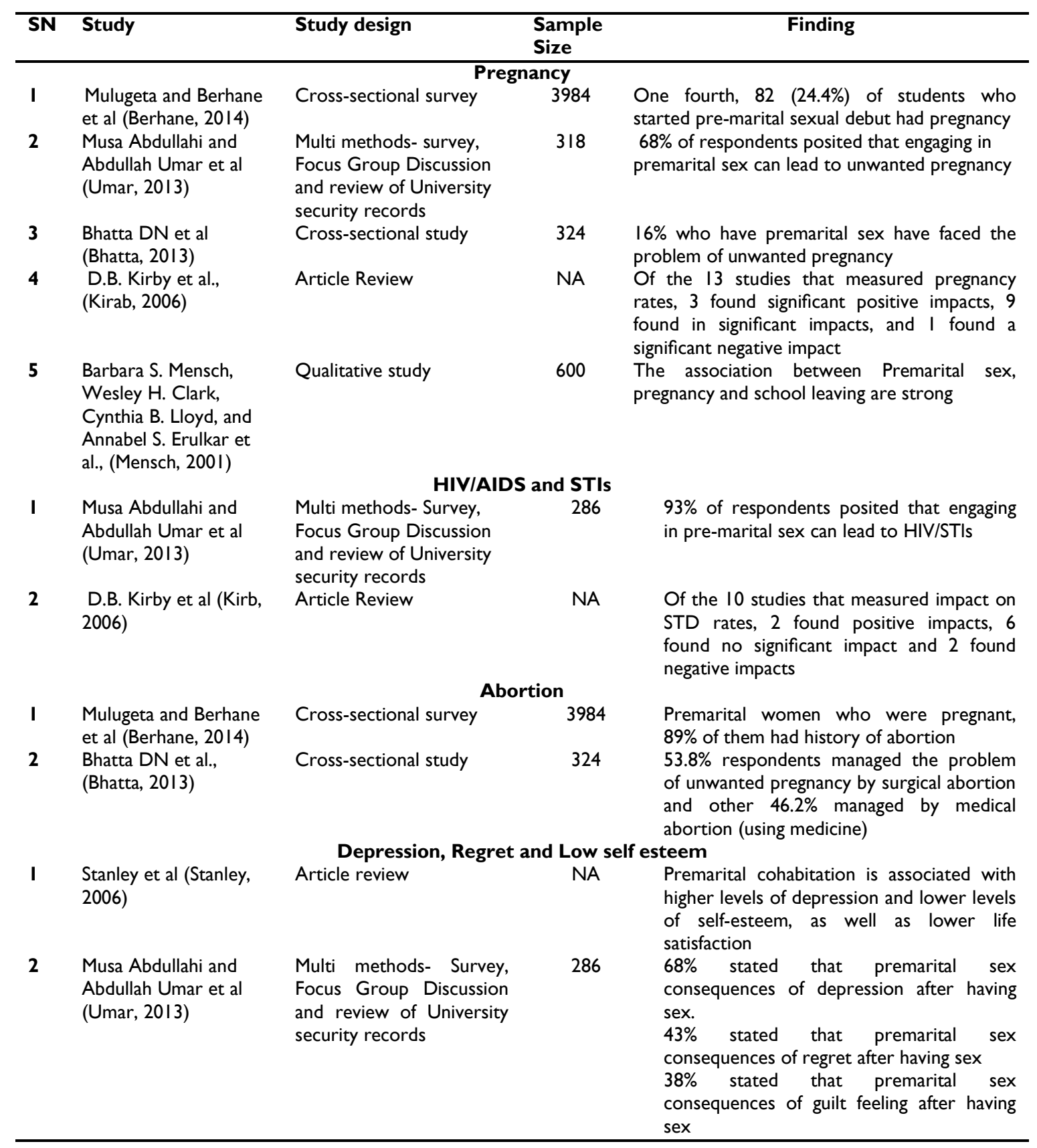




\section{Discussion}

Discussion has been made with dividing four areas of the study like individual level, family level, institutional level and impacts of premarital sex on adolescents' health as follows:

Individual level factor for having premarital sexual behaviour

Age, sex, peer relationship/love and affair are important factors for having premarital sex. Review article studies show late adolescents affair are especially 18-19 as most common to have premarital sexual behaviour than early adolescents. Male show more significant sexual relationship than female. Studies also show sexual behaviours with in good peer is significantly less than poor peer norms. Higher number of the adolescents have sexual relationship with their girlfriends.

\section{Family Level Factor for Having Premarital Sexual Behaviour}

Home is the first school for learning and mother is a first teacher. Family environment directly have relationship between premarital sexual behaviour in adolescent period. During adolescent, family should support and take proper care towards them. The review studies show that parental relation also considered as one of the important factors that lead to premarital sexual behaviour of their children. Especially, mother have greater roles than other members in the family.

\section{Institutional Level Factor for Having Premarital Sexual Behaviour}

Adolescent sexual health is multi-dimensional. From review articles, it is also concluded that, there is a direct relationship within institutional level factor for having premarital sexual behaviour. Rules and regulation, policies, community leader, community organization, education institutional environment and communication facilities including internet have direct and indirect relationship with adolescent sexual behaviour, especially premarital sex.

\section{Health Impact of Premarital Sexual Behaviour among Adolescents}

Health of adolescent is very crucial. Different research reports and literature show that the incidences of premarital sexual behaviour have been increasing anywhere even it is considered as illegal, shame, adultery, guilt fornication and so on. Premarital sexual behaviour among adolescents leads to direct and indirect impact on health. Unwanted pregnancy, teenage pregnancy, abortion, STI, HIVIAIDS, regrets, loss of self-respect, depression, loss of family support, substance abuse and even death (suicide) are health impact of premarital sexual behaviour among adolescents.

\section{Conclusion}

According to WHO boys and girls during the age group of $10-19$ called as adolescents. There is drastic change and development in physical, cognitive, social and emotional aspects during adolescence. In this age, everybody has common question of "Is it ok to have premarital sex?" 
The thought might be different from each other. Premarital sexual behaviour or sex before marriage is the sexual activity between two people who are not married.

From review literature, there are multidimensional factors, which leads to premarital sexual, behaviour. Parent relationship with their children and family environment, societal environment, cultural and traditional rules and values, economic condition, school environment, peer's relationship, love and affairs, communications (mobiles, internet-pone movies etc.) and rules and regulation are the risk factors that affect in premarital sexual behaviour of adolescents.

Furthermore, study found that family, culture and religion do not give permission to have premarital sex. Along with this premarital sexual behaviour have negative impact on health of adolescents like unwanted pregnancy, substance abuse, depression, suicidal death, loss of selfesteem and loss of family support.

\section{References}

Adhikari, R. \& Tamang, J. (2009). Premarital sexual behaviour among male college students of Kathmandu, Nepal. BMC. Public Health, 9:24I Retrieved from https://doi.org/I0.1/86/147I2458-9-24I

Barbara S. \& Mensch, W. H. (200I). Premarital sex, schoolgirl sregnancy, and school quality in rural Kenya. Retrieved from https://www.ncbi.nlm.nih.gov/pubmed/I I831048

B C, G. B. \& Basel, P.L. (20I3). Premarital sex behaviors among college youths of Kathmandu, Nepal. Kathmandu University Medical (KUMJ) I I (4I), 27-3I.

Berhane, Y. M. (20I4). Factors associated with pre-marital sexual debut among unmarried high school female students in Bahir Dar town, Ethiopia: Cross- sectional study. Reproductive Health, 2-6. Retrieved from http://www.reproductive-health-journal.com/content/ I I/I/

Bhatta, D N (20/3). Adolescent students' attitude dtowards premarital sex and unwanted pregnancy. Health Renaissance, II, 145-149. Retrieved from https:/www.nepjol.info/index.php/HREN/article/view/8222/6687

Brent, C. Miller, B. B. (200I). Family relationships and adolescent pregnancy risk: A research synthesis. developmental review, $2 I(I), \quad 1-38$. Retrieved from https://www.sciencedirect.com/science/article/pii/S0273229700905I 36

Cavendish, M. (2010). Sex and society. Retrieved from https://en.wikipeida, org/wiki/premaital_Sex

Chai Podhisita, P. X. (200I). The risk of premarital sex among Thai youth: Individual and family influences. East-West Center Working Papers. Retrieved from https://www.files.ethz.ch/isn/I01291/200 I_10_The_Risk_of_Premarital_Sex.pdf

Chiao, C. (2012). Exploring the relationship between premarital sex and cigarette/alcohol use among college students in Taiwan: a cohort study. BMC Public Health. Retrieved from https://www.ncbi.nlm.nih.gov/pubmed/22809432

Christian Bible Reference Site. (2016). Google. Retrieved from https://www.christianbiblereference.org/faq_premaritalsex.htm

Fieser, J. (2017). Sex from oral issues that divide us. Retrieved from https://www.utm.edu/staff/ jfieser/class/I60/2-sex.htm 
Finer, L.B. (2007). Trends in premarital sex in the United States, 1954-2003. Public Health Rep. 2007 Jan-Feb; I22(I): 73-78. doi I0.1 I77/0033354907I 2200II0

Kirby, D.B. (2007). Sex and HIV education programs: Their impact on sexual behaviors of young people throughout the world. Journal of Adolescent Health, 206-217. Retrieved from http://www.sidastudi.org/resources/inmagic-img/dd289l.pdf

Laura Gibney, N. S. (2003). Behavior risk factors for STD/HIV transmission in Bangladesh's trucking industry. Soc sci med Apr 56 (7): |4|I-1424. Retrieved from http://s I 16768.gridserver.com/sites/default/files/content/pphg/surveillance/CDCMARPs/resources/multi-stage-cluster/5.pdf

Ministry of Health and Population (MOHP) [Nepal], New ERA, and ICF International Inc. 2012. Nepal Demographic and Health Survey 201I. Kathmandu, Nepal: Ministry of Health and Population, New ERA, and ICF International, Calverton, Maryland.

Paudel, D. R. (2013). Attitude on premarital sex, marriage and family size among adolescents in Pokhara Valley. JHAS, 3, 60-63.

Population Division/MoHP (2010). Nepal adolescent and youth survey 2010/201I. Population Division, Government of Nepal, Ministry of Health and Population. Retrieved from https://nepal.unfpa.org/en/publications/nepal-adolescents-and-youth-survey-20I0I I-highlights

Pradhanaga, Y. (2018). Class presentation. Goathgau: Morang.

Puri, M., \& Cleland, J. (2006). Sexual behavior and perceived risk of HIVIAIDS among young migrant factory workers in Nepal. Journal of Adolescent Health, 38, 237-246.

Roberts, S.T \& Kennedy, B. L. (2006). Why are young college women not using condoms? Their perceived risk, drug use, and developmental vulnerability amay provide important clues to sexual risk. Arch Psychiatric Nurs. Feb; 20 (I): 32-40. Retrieved from https://pdfs.semanticscholar.org/bda0/02325794c5fc5519cec4fce3ba5facd3480 I.pdf

Sawyer, S.M (2012). Adolescence: A foundation for future health. Retrieved from https://www.ncbi.nlm.nih.gov/pubmed/22538I78

Stanley, S.M. Rhoades, G. K. \& Markman, H.J. (2006). Sliding versus deciding: Inertia and the premarital cohabitation effect. Family Relation International. Journal of Applied Family Studies, 55(4), 499-509. Retrieved from https://www.jstor.org/stable/40005344?seq= I\#page_scan_tab_contents

Umar, D. M. (2013). Consequences of pre-marital sex among the youth a study of University of Maiduguri. IOSR Journal Of Humanities And Social Science (IOSR-JHSS), 10 (I), 10-17. Retrieved from http://www.iosrjournals.org/iosr-jhss/papers/Voll 0-issuel/B0101 I017.pdf

UNICEF (200I). Teenage births in nations. Retrieved from https://www.unicef.ircorg/ publications/odf/repcardse.pdf

United Nations - Youth. (2003). World youth report 2003. Retrieved from 8. https://www.un.org/development/desa/youth/world-youth-report/world-youth-report2003.html

Wildmer, E.D., Treas, E. \& New Cobb. R. (1998). Attitudes toward nonmarital sex in 24 countries. The Journal of Sex Research, 35 (4), 349-358. Retrieved from http://www.jstor.org

Yi, C. C.-C. (20II). Adolescent premarital sex and health outcomes among Taiwanese youth: perception of best friends' sexual behavior and the contextual effect. AIDS Care Psychological and Sociomedical Aspects of AIDS/HIV, 23(9). 